surprising. That prospect has always been part, but by no means the whole, of the justification of this important and exciting project.

So what arrangements will there be in the Human Genome Project? Even if the project is financed exclusively by agencies of the US government, it is unthinkable that its product should be regarded as a resource exclusively at the disposal of US biotechnology and pharmaceutical industries. Restrictions on access necessary to secure that would undermine the enthusiasm of sequencers in the scientific community, would conflict with the institutional obligations (to publish) of many of those participating and would rid the project of its other justifications, not least its bearing on the evolution of gene systems and even whole species.

But the Human Genome Project is not a project just to produce a single sequence, but one to understand both how the human genome functions and its relationships with the genomes of other species. If US biotechnology considers a human genome sequence would be worthwhile, it should get itself an anti-trust waiver, club together and produce one, with whatever confidentiality it considers appropriate. The project the US Congress is being asked to support is a different project, one that is worthwhile in its own right, but which may bring incidental commercial benefits as well. It should be an international project, intellectually as well as financially.

Watson's show of xenophobia last week was almost certainly directed at Japan, whose government has been slow in agreeing to contribute $\$ 300,000$ to HUGO, the embryo organization designed as a framework for sharing the labour. Unless that can be made to function, the US Congress should keep its money in its taxpayers' pockets.

\section{Catalogue of errors}

The British government needs to learn from the way it has damaged its own research enterprise.

GOVERNMENTS everywhere have well-tried ways of avoiding unwelcome advice. One is to respond energetically to the least unpalatable bits and to ignore the rest. That is how the British government responded, in 1982, to the trenchant and prophetic complaints of the House of Lords Select Committee on Science and Technology about the neglect of British science. Radical proposals, cabinet representation for research for example, were swept aside, but the government did promise an annual review of spending on research in Britain. But even that seemingly innocuous promise has now back-fired, for the government now finds itself recording the consequences of its own failings (see page 3 ).

Especially because last week's abrupt resignation of the chancellor of the exchequer may induce an unwonted inclination to reflection, the British government should now ask how its good intentions and the seeming logic of its policies can have so damaged the scientific enterprise.
There is no doubt of the government's commitment, when elected 10 years ago, to the view that science and technology are the sources of innovation and are thus public goods. But it was frustrated that seemingly high public spending on research and development yielded so little commercial benefit. It was also moved by animus against British universities, whose academics were judged to include too many genteel layabouts.

Three strands of policy have done the damage. The enforced monetary restraint between 1979 and 1983 damaged the research budgets of public agencies, more than offsetting the prime minister's promise that research council spending would be "protected", but the effects have since been continued by the indolence of ministries towards research and, more recently, by the decision that "near-market" projects should be supported by industry, not the public purse. That might make sense if there were an objective measure of how near is "near", but this has been but part of a long struggle to put the cart before the horse. The government believes that industry, not taxpayers, should pay for applied research, which would be correct in an ideal world. In the real world, the government cut back, but industry only barely took up the slack.

Second, despite saying that governments should not interfere, this government has been a veritable busybody, urging research agencies to spend funds on developments in technology of all kinds, as well as creating circumstances, in which funds intended for research had to be spent on reorganization and the early retirement of researchers. This journal's frequently repeated view that the research councils could have responded more effectively does not excuse the pressure, or its shortsightedness.

Third, the government has consistently underestimated the importance of higher education and training. Its suspicion of the universities may explain the indifference of its early period, when it hoped that student numbers would decline, but the shortages of novel skills apparent throughout the decade should have moved it in the other direction. There is no knowing whether its conversion this year to increased enrolments will be in time or whether it will be feasible. Meanwhile, it is no surprise that the proportion of young graduates in science and engineering (a stagnant total) seeking careers in science and technology is declining. Why enter a demoralized and badly paid profession when there is a better life elsewhere?

The consistent underlying error is the British government's failure to appreciate the gap between intentions and reality. In its treatment of research, as elsewhere, it has been seeking to effect a revolution - less direct support from government (as in Japan), more creative relationships between academic research and industry (as in the United States) and a greater responsibility on the part of students for their own educations, as well as a greater sense of its importance. The objectives have been clear. But having identified them, the government has adjusted its own behaviour and its budgets to conform, forgetting that the compensating behaviour required of the others has not usually been forthcoming. 